\title{
BALTHASAR HUBMAIER: THE THEOLOGIAN OF THE ANABAPTISTS. NIKOLSBURG AND CATECHETICAL INSTRUCTION: A LABOR OF LOVE
}

\author{
JASON J. GRAFFAGNINO* \\ Truett McConnell University
}

\begin{abstract}
Balthasar Hubmaier is often called 'the theologian of the Anabaptists' for he was the only early Anabaptist leader with an earned doctorate. The former Catholic priest embraced the reforming thought of Erasmus, Zwingli, and eventually Zwingli's former pupils (the Anabaptists) and led the Moravian city of Nikolsburg to become a bastion of Anabaptist thought and practice. The multi-dimensional religious landscape both afforded Hubmaier the opportunity and compelled him to author the first Anabaptist catechism. Through the work, Hubmaier articulated a clear and succinct portrayal of Anabaptist theology and ecclesiology summed up in the Erasmian tenet of the love of God and neighbor.
\end{abstract}

KEY WORDS: Balthasar Hubmaier, Anabaptism, Catechism, Nikolsburg, Erasmus

\section{Introduction}

Balthasar Hubmaier arrived in Nikolsburg (modern-day Mikulov, Czech Republic) in South Moravia in June or July 1526. The Anabaptist reform he had established at Waldshut in 1525 had come to an end in December at the hands of the Hapsburgs. He fled to Zürich, where he recanted of his Anabaptist faith under duress from Zwingli. Hubmaier next arrived in Augsburg in May 1526. Bergsten surmised that Hubmaier may have met Hans Hut in Augsburg since Hut was baptized there by Denck in early June 1526. Hubmaier also interacted with Urbanus Rhegius, an Erasmian humanist, in Augsburg. Hubmaier and Rhegius had studied together in Freiburg and Ingolstadt (Bergsten 1978: 300-15). Though Hubmaier was not expelled from Augsburg, he soon left that free city for the town he later allegorized as 'the house on the rock, built on the foundation of Holy Scripture and 
shining forth its light (alluding to the name Liechtenstein)'. Hubmaier had declared Nikolsburg 'the lighthouse of the Reformation' in place of Wittenberg (Rothkegel 2007: 169; Hubmaier 1989: 317-19; Hubmaier 1962: 28889). This study will espouse the idea that it was at Nikolsburg where Hubmaier had his greatest success as an Anabaptist leader and theologian through his influence upon other reformers in the area and through his catechism that clearly defined Anabaptist theology and ecclesiology by the overarching tenet of the love of God and neighbor.

\section{Nikolsburg: the Lighthouse of the Reformation}

When Hubmaier arrived in Nikolsburg the town was a bastion of religious liberty and religious multi-dimentionalism. The Unitas Fratrum was an indigenous tolerated religious minority with well-known theological tenets. Initially, the elites among the nobles and clergy were influenced by Erasmian Christian humanism. Also, there were reform-minded Catholics and Utraquists who had banded together to form a joint unofficial coalition. From 1524 on, Nikolsburg transitioned into a multi-faceted hub of radical religious thought and reforming ideas (Rothkegel 2007: 165-66).

The Liechtenstein Lords, governors of the town, were probably introduced to evangelical reforming thought by Hans Spittelmaier, who published Entschuldigung (Apology, 1524) on 6 March (Bergsten 1978: 315; Zeman 1969: 84). Spittelmaier claimed that he was the chaplain of the Liechtenstein Lords. He possessed a detailed knowledge of monastic life, indicating that at one time he may have been a monk. He was well versed in Latin and Greek and wrote in a clear and clever apologetic style that rivaled that of Hubmaier. Spittelmaier also stated that he had preached the gospel in Nikolsburg for a long time, preaching Christ alone and 'setting aside and destroying all kinds of sects and schisms'. However, apart from a single autobiographical reference and some scant references in a few Anabaptist sources from 1526-28, nothing else is known of his life prior to his arrival in Nikolsburg (Zeman 1969: 84).

Spittelmaier was at odds with Franciscan monks in the nearby Austrian town of Feldsberg. He wrote Entschuldigung in reply to the monks' repeated attacks against him (Zeman 1969: 84). Spittelmaier assailed the hypocrisy and arrogance of the monks as evidenced by their worship of images, greed, unchastity, and their vestments. His understanding of the Christian faith echoed Luther's views (Bergsten 1978: 315).

Martin Göschl was another important player in the Nikolsburg religious context. In terms of social prestige, Göschl was the most prominent leader of early Moravian Anabaptism (Vedder 1905: 150-51). Göschl was a learned humanist, as many of the elite members of clergy were (Rothkegel 2007: 166). He served as Coadjutor Bishop of Olomouc from 1509-26, and also 
functioned as the provost of a nunnery near Kanitz from 1517-26. The other preachers in Nikolsburg were newcomers, but Göschl was a well-known and well-respected man in both ecclesiastical and political circles and a native southern Moravian (Zeman 1969: 181-82).

By 1522/23 Göschl had been guided toward evangelical thought by Paul Speratus. Speratus was born the year after Luther, 1484, near Augsburg. He studied philosophy, theology, and law in Paris, Italy, and Vienna. He earned terminal degrees in all three fields. In February 1519, he was appointed preacher at the cathedral in Würzburg, but because he held evangelical views and he was married, he was expelled from the city. After short stays in Salzburg and Vienna, Speratus stopped in the border city of Jihlava (Iglau), Moravia and helped spread Luther's views there. Under pressure from Bishop Thurzo of Olomouc the king had Speratus arrested and brought to Olomouc in April 1523. He was condemned to death by fire for his Lutheran views. Due to the intervention of several influential leaders, including Georg, the Margrave of Brandenburg, he was released in July 1523. He served as Lutheran Bishop of Pomesania, Prussia from 1530 to 1551 . He occasionally met with Anabaptist refugees from Moravia, including Spittelmaier and Glaidt in December 1531, and welcomed the Czech Brethren when they sought refuge in Prussia in 1548 (Zeman 1969: 83).

Göschl married a nun from the Kanitz nunnery and closed down the convent in 1526. He was forced to leave his ecclesiastical offices, but before he did so he ordered the clergy of Nikolsburg to take part in the Austerlitz disputation (Bergsten 1978: 319). Göschl and several Utraquist nobles convened the meeting of Catholic and Utraquist priests who were in favor of reforming ideas (Rothkegel 2007: 166). Göschl supported Dubčanský's efforts toward religious unity, and in May 1526 he moved with his wife to Nikolsburg (Bergsten 1978: 319-20).

Oswald Glaidt, who arrived in Nikolsburg in 1525, compiled and published an account of the Austerlitz discussion conducted by Dubčanský. It was entitled Handlung (Action, 1526) (Bergsten 1978: 316-17; Zeman 1967: 118-19). Glaidt had been a monk in Leoben, Austria, but began preaching openly the Word of God and was thrown into prison and eventually banished from the country (Bergsten 1978: 316-17).

Glaidt recorded that the Austerlitz debate consisted of mainly clergy with a few laypersons in attendance. There were approximately three hundred persons, including over one hundred fifty German ministers, although some scholars question the actual number of German ministers who were present (Zeman 1969: 97). The debate concluded with an agreement that consisted of seven articles. The articles affirmed 'that only the Word of God should be preached, that the servants of the Word should be allowed to marry, and that holy water, candles, and similar things which are 'outside 
the Scriptures' and lead to superstition should be removed' (Bergsten 1978: 317-18).

The articles also described the Lord's Supper as the table of 'remembrance' of Christ. There was a sharp distinction presented 'between an inner, spiritual communion and an external, symbolic meal'. In that language of the Supper, Rothkegel recognized a variation of 'the Zwinglian Eucharistic theology' which had been promoted in Bohemia by the Unitas Fratrum member Zeising (Rothkegel 2007: 167).

Baptism was not discussed among the seven articles; however, Glaidt did include a discussion of baptism in his commentary notes about the article on the Lord's Supper (Zeman 1969: 99-100). Glaidt's notes hold to a symbolic understanding of the Lord's Supper and baptism, similar to that of Zwingli and Hubmaier. Glaidt however defended infant baptism in his commentary notes included with the report, indicating that he had not yet been swayed to join the Anabaptist movement (Bergsten 1978: 318).

When Hubmaier arrived at Nikolsburg in 1526 he found a populace which was open to evangelical reform. This was evident later through the rapid Anabaptist growth in Nikolsburg and other parts of southern Moravia. Spittelmaier and Glaidt had established the base upon which Hubmaier could build (Bergsten 1978: 319).

On 21 July 1526 in Oswald Glaidt's room in Nikolsburg, Balthasar Hubmaier dedicated his Der uralten und gar neuen Lehrer Urteil (Old and New Teachers on Believers Baptism, 1526) to Martin Göschl. Hubmaier described Göschl as 'the only bishop [he had] experienced who [had] surrendered himself on earth so powerfully and faithfully to God and his holy Word in doctrine and works', and 'in a wholly valiant and manly fashion' (Hubmaier 1989: 249; Hubmaier 1962: 229). This was Hubmaier's first published work in Nikolsburg, and from the very beginning, he endeavored to associate positively with the evangelical clergy who were already present (Bergsten 1978: 320). In Old and New Teachers on Believer's Baptism Hubmaier demonstrated for his fellow clergy and others who would listen, that the Bible, the Church Fathers, and the teachers of the Church favored 'believers' baptism' and opposed infant baptism (Hubmaier 1989: 245).

Hubmaier's new teaching soon influenced Glaidt, Göschl, Spittelmaier, and Zeising. In fact, it is important to note that one semi-Lutheran (Spittelmaier), one Zwinglian (Glaidt), one Catholic / Utraquist reforming humanist (Göschl), and one Lutheran / Unitas Fratrum / Zwinglian / Habrovanian Brethren (Zeising) all professed infant baptism before Hubmaier arrived in Nikolsburg. However, within just a few months all four of them accepted believer's baptism through the ministry, preaching and teaching of Balthasar Hubmaier (Bergsten 1978: 320; Graffagnino 2013). In the preface to Ein einfältiger Unterricht (A Simple Instruction, 1526), Hubmaier commended 
Spittelmaier and Glaidt as ministers "who so valiantly and comfortingly show the bright light of the gospel and set it on a candlestick, the like of which [he had] neither yet known nor seen in any place on earth' (Hubmaier 1989: 317; Hubmaier 1962: 288). At the end of his Eine Form des Nachtmahls Christi (A Form for Christ's Supper, 1526), Hubmaier called Zeising his 'dear brother (meinen lieben brüder Jan Zeysinger)' (Hubmaier 1989: 408; Hubmaier 1962: 365). This affectionate language showed that Hubmaier knew Zeising rather well, and that he probably had baptized Zeising before this document was written in late 1526, or early 1527. From these statements, it became clear that Hubmaier had developed significant relationships among the German evangelical ministers in Nikolsburg in a brief period of time. Several of these men would meet the same fate as Hubmaier (Zeising was martyred in Brünn in 1528; Glaidt was martyred in Vienna in 1546) (Hubmaier 1989: 317, 408).

\section{Hubmaier and Humanism}

Erasmus' involvement in reforming ideas was evident. Besides his ongoing debate with Luther, other Reformers who read and studied Erasmus' works included: Zwingli, Melanchthon, Johannes Bugenhagen (Luther's spiritual advisor), Martin Bucer, Caspar Schwenckfeld, Valentin Crautwald, Hans Denck and Hubmaier, among others (Steinmetz 2001: 50, 58, 85-90, 131, 146).

Valentin Crautwald was a Spiritualist in the Reformation who answered Erasmus' call for catechization. The key for Crautwald was 'public' catechism, or the idea of catechism as an integral part of public worship. In May 1526, he wrote two letters to a pastor in Breslau, Michael Wittiger, encouraging him to implement catechization and said, 'Our whole ministry of the Word is now public catechism. I say that this matter is timely and should be brought into the open and established lest the people stray and are seduced by the vain label of Christianity. I think that the glory of the Gospel, which is now coming to life again, should be promoted by catechism' (Shantz 1992: 61). Shantz ably demonstrated that Crautwald was aware of Erasmus' emphasis on catechetical instruction.

In Old and New Teachers on Believer's Baptism, Hubmaier quoted Erasmus' statement from his Paraphrase of Matthew (March 1522) (Erasmus 1974-2004: 50: 334) that, 'After you have taught the people... and they believe what you have taught them, have repented of their prior life, and are ready henceforth to walk according to evangelical doctrine, then immerse them in water in the name of the Father and the Son and the Holy Spirit' (Hubmaier 1989: 255; Hubmaier 1962: 233). Hubmaier concluded that Erasmus pointed out 'that baptism was instituted by Christ for those instructed in faith and not for young children' (Hubmaier 1989: 255; Hubmaier 1962: 233). 
Hubmaier's initial exposure to Christian humanism dated back to 1511 , when he became associated with the faculty at the University of Freiburg, which was a hub of Christian humanist inspired reform (Davis 1974: 101). Hubmaier composed a poem about John Eck in 1516, which focused on the humanistic tenet of classicism and therefore revealed the former's interest in humanism (Bergsten 1978: 74). In early 1521 at Waldshut Hubmaier became enamored with humanism and began reading Erasmus (Snyder 1995: 56). He developed relationships with several well-known humanists during that time including Johannes Sapidus and Beatus Rhenanus. Hubmaier wrote a letter to Wolfgang Rychard, a physician in Ulm, and called him 'his dearest friend and brother'. Rychard was not only an important physician, but he was also the leading humanist in Ulm. Rychard collected and circulated pro-Reformation writings. Bergsten surmised that Rychard had passed on Oecolampadius' Judicium on Luther to Hubmaier during his time in Ulm. Bergsten concluded that Hubmaier's involvement with Rychard provided evidence of Hubmaier's interest in the 'new teachings' of the Reformation (Bergsten 1978: 70-72). Bergsten believed that Hubmaier's relationship with Rychard was significant in the former's 'spiritual development' (Bergsten 1978: 72).

In 1521 Hubmaier wrote Sapidus a letter and informed him that he honored theologians above all scholars, and particularly those that held to Pauline 'theosophy', the chief of which was Erasmus. Hubmaier also informed Sapidus that he had rejected scholasticism, in favor of the humanist ideal, and that he yearned for more dialogue with humanist and evangelical Reformers (Bergsten 1978: 72-73; Davis 1974: 101).

Eight months after writing Sapidus, Hubmaier penned a letter to Johann Adelphi on 23 June 1522 (Zeman 1969: 125). Adelphi was a physician and reforming humanist in Schaffhausen. He was a voracious writer, a friend of Erasmus, and he translated some of the great scholar's works into German. The two men, Hubmaier and Adelphi, exchanged letters several times, the substance of which indicated that they shared humanist interests. In the aforementioned letter, Hubmaier shared with Adelphi about his recent trip to Basel and Freiburg. He described Freiburg as a 'captive' city filled with dissension and division due to the evangelical reforming ideas. In Basel, Hubmaier saw a city with strong humanist ties and open to reform. Hubmaier developed personal relationships with those in the Basel humanist circle and those receptive to evangelical reform, including Rhenanus (Bergsten 1978: 73).

It was that trip in early June 1522 where Hubmaier at Basel met with the persons he called his 'best friends', Erasmus, Glarean, and Pelikan. Hubmaier and Erasmus discussed 'purgatory' and a key verse regarding new birth, John 1: 13, which stated that Sons of God were born "neither by 
the will of the flesh nor by the will of man'. Regarding Erasmus, Hubmaier ascertained that he 'spoke freely but wrote sensibly' (Zeman 1969: 125; Bergsten 1978: 73-74). Pertaining to Hubmaier's assessment that Erasmus 'wrote sensibly', Halkin raised the question: 'To what work was Hubmaier referring?' Halkin proposed it was plausible that Hubmaier had just read Erasmus' preface to his 1522 NT, which had just been published. Hubmaier may have found Erasmus' call for a renewal of baptism refreshing, but insufficient. Halkin surmised that Erasmus' text may have fascinated Hubmaier but failed to give him full satisfaction because a renewal of baptism was 'not an actual baptism' (Halkin 1993: 166). However, by June 1522 Hubmaier had not even joined the ranks of the evangelicals! Bergsten asserted that by 1523, whatever doubts he may have had concerning infant baptism, Hubmaier had not considered the possibility of rebaptism (Bergsten 1978: 81). Halkin's assessment of Hubmaier's skepticism of Erasmus' call for a renewal of baptism was shortsighted. Instead, it is plausible that Erasmus' call may have stimulated Hubmaier's own thought on baptism indicated by the fact that Hubmaier later cited the famous humanist's baptismal views when he discussed the true meaning of baptism (Hubmaier 1989: 255-56; Hubmaier 1962: 233).

Erasmus feared that there were many Christians 'only in name' and that true Christianity exhibited by philosophia Christi was not being lived out in his day. Hubmaier echoed similar sentiments in his Achtzehn Schlußreden (Eighteen Theses, 1524). Hubmaier's discussion of Christians 'in appearance [only]', and of a faith which makes a person 'righteous (fromm)' and 'must break forth (außbrechen) in gratitude toward God' through the 'works of brotherly love toward others (in allerley werck brüderlicher liebe)', paralleled Erasmus' concerns (Hubmaier 1989: 32; Hubmaier 1962: 72).

Hubmaier's Von der christlichen Taufe der Gläubigen (On the Christian Baptism of Believer's, 11 July 1525) was addressed to the Zurich Council and Zwingli, although the latter's name was never mentioned' (Hubmaier 1989: 97; Hubmaier 1962: 119). Hubmaier saw the 'true baptism of Christ (den rechten Tauff Christi)' as a 'public confession and testimony of internal faith and commitment (offenliche bekantnü $\beta$ vnd zeügnüß des inwendigen glaubens) by which the person also testifies outwardly (außwendig bezeügt)' and one in which the believer was committed and determined 'to live according to the Word and the command of Christ' through the 'power of God the Father, the Son, and the Holy Spirit' (Hubmaier 1989: 100-01; Hubmaier 1962: 122). Hubmaier then presented his reason for such a public display of baptism:

Now, so that the kingdom of Christ might increase, the person breaks out into word and deed (Yetz bricht der mensch auß in wort vnd wreck). He proclaims and magnifies the name and the praise of Christ, so that others might also become 
sanctified and be saved through him in word and faith, in the same way as he also came to faith and the knowledge of God through other people who preached to him about Christ (Hubmaier 1989: 101; Hubmaier 1962: 122).

In the foreword to his Greek-Latin New Testament (1522), Erasmus had made a similar declaration regarding the baptism of catechumenates. A public renewal of baptism after catechization was essential because it would demonstrate a clear affirmation of faith and commitment to live for Christ.

Hubmaier directly quoted Erasmus' Paraphrases on both Matthew and Acts in Old and New Teachers on Believers Baptism. Hubmaier emphasized Erasmus' own declaration that 'after you have taught the people' and 'they believe... have repented... then immerse them in water' (Hubmaier 1989: 255-56; Hubmaier 1962: 233). The key for Hubmaier and Erasmus was that instruction (catechization) was to take place prior to 'true' baptism. Even though Erasmus in his later writings back-tracked on much of what he wrote in 1522, Hubmaier appears to have sought to implement a similar proposal and vision.

\section{On the Freedom of the Will}

On the matter of the 'freedom of the will' Erasmus and Hubmaier were like-minded. The subject was the center of one of the most hotly contested debates of the Reformation era involving Erasmus and Luther. Erasmus' De Libero Arbitrio (1524) was answered by Luther's De Servo Arbitrio (1525) (Hubmaier 1989: 426). Hubmaier, just as Erasmus, held to the pro free will position. He initially addressed the topic in his Lehrtafel (A Christian Catechism, 1526/27). The Nikolsburg free will debate was a heated one in which Hubmaier's view was initially rejected. Hubmaier's friends and opponents, through scriptural appeals, attempted to eradicate the so-called 'freedom' that he was espousing. Hubmaier's opponents held that God evoked good and evil in human beings according to a divine decree. The person was not capable of doing good apart from God's working (Bergsten 1978: 349). Subsequent to his catechism, Hubmaier wrote two additional works, Von der Freiheit des Willens (Freedom of the Will I, 1 April 1527), and Das andere Büchlein von der Freiwilligkeit des Menschen (Freedom of the Will II, 20 May 1527), which further presented his free will position (Hubmaier 1989: 426-91; Hubmaier 1962: 379-431).

Hubmaier summarized his view on free will in his Lehrtafel:

First God made us good and free (gütt vnd frey) in soul, body, and spirit. This goodness and freedom (güthayt wnd freyhayt) were through Adam's disobedience taken captive in our spirit (am Geyst gefangen), wounded in our soul (an der Seel verwundt), and completely corrupted in our flesh (an dem fleysch gar verderbet worden); therefore, we are all conceived and born in sin and are by nature the 
children of wrath (daher wir all in den sünden, vnnd khinder des zorns von nature entpfangen ond geborenn). If we are now again to become free in the spirit (an dem Geyst frey) and healthy in the soul (an vnnser Seel gesunnd werden), and if this Fall is to be made completely harmless in the flesh (am fleysch gar wnschedlich sey), then this must take place through a rebirth (durch einn widergeburt), as Christ said, or we shall not enter into the kingdom of God, John 3: 5. But now God has given birth to us of his own will (Nun hat vnns aber Got willigklich geborenn), as James writes, James 1: 18, and Peter, 1 Peter 1: 3, by the word of his power in which we are really made whole and free again (wir auff einn newes erst recht frey ond gesund werden). Christ likewise says, the truth will make you truly free (Die warhayt wirdt euch warlich frey machenn), John 8: 22, and David, he sent forth his Word and healed us, Psalm 106 [Psalm 107: 20]. Yes, to the present day through the Word God sent (durch das gsendt wort Gots), our souls are just as free in themselves to will good and evil as was Adam's soul in Paradise (vnsere Seelen sind... güts vnd bö $\beta$ ze wölln als frey in inen selbs, als die seel Adams im Paradeiß was) (Hubmaier 1989: 361; Hubmaier 1962: 322-23).

The crux of Hubmaier's doctrine of free will was that the soul may become 'healthy' as it was before the Fall and able to do good. The health of the soul is restored when it becomes 'born again (wiedergeboren)' through the Holy Spirit and the Word of God (Bergsten 1978: 350). The person is 'restored or brought back (wiederbringen)' to his or her condition prior to the Fallthe 'image of God (die Bildung Gottes)' - and regains 'true health and freedom' (Hubmaier 1989: 361, 435; Hubmaier 1962: 322, 390). However, the 'born again' soul is now torn between the wicked flesh and the blameless spirit, and faced 'with the possibility of rejecting anew the grace received' (Bergsten 1978: 350). The 'freedom of the will is freely given to [the person], like a cut-down tree, to fall on one side or the other' (Hubmaier 1989: 451; Hubmaier 1962: 401).

Hubmaier's doctrine of free will included aspects of the image of God, freedom of the will, and the Word of God. Pertaining to the image of God, he said, 'If before the Fall God's likeness was free and unbound in us, since the Fall it is held captive and the sin of the Fall is damning. After the restoration of the Fall through Christ, this likeness is made free again, although captive in the sinful and poisoned body; but the curse has been removed from the sin of the Fall.' Referring to Romans 8: 13, Hubmaier described the imago Dei as the 'inbreathing of God (Anhauchung Gottes)' and as 'a live spark covered with cold ashes (vnnd als ein feüflen zůgedeckt mit kaltem eschen)' which was 'still alive (noch regt sich das feürlen)' (Hubmaier 1989: 360; Hubmaier 1962: 322). According to Hubmaier the body was part of the imago Dei prior to the Fall, but after the image of God became imprisoned by the body. The 'live spark' was given to humanity in creation; Hubmaier showed the divine origin of the spark by referring to it as the 'in-breathing' and the 
'breath of God' (Hubmaier 1989: 360; Hubmaier 1962: 322; Bergsten 1978: $351)$.

Hubmaier depicted freedom of the will as a "power, force, energy, or adroitness of the soul to will or not will something, to choose or flee, to accept or reject good or evil, according to the will of God, or according to the will of the flesh' (Hubmaier 1989: 443; Hubmaier 1962: 393). Free will has been preserved 'in the spirit of [a person] and to a certain degree also in his soul, even after the Fall'. A person's ability to 'do good' was lost in the Fall, and for the flesh there was no longer any free will. Through restoration, the soul achieved liberation and regained the capacity "to desire and to achieve what is good' (Bergsten 1978: 351).

Hubmaier saw the liberation of the soul as God's work through his Word. When he spoke of free will the 'Word' which set humanity free was 'the preached Word of God (dem gepredigten wort Gottes) whose sound goes throughout the whole world'. Hubmaier saw 'the preached Word' as the bearer of conviction of 'the gnawing worm into the heart of the human being'. By the grace of God, the ability to choose was offered 'through his preached Word' to the person so that he or she 'in [his or her] power' could decide to become a child of God. By God's 'preached Word' the fallen person becomes born again by the Spirit of God. Without the work of the Holy Spirit the 'Word' would be a 'killing letter (todtender buichstab)' (Hubmaier 1989: 431, 463, 468; Hubmaier 1962: 383-84, 410, 413).

Hubmaier's writings on free will showed him to be a sympathizer of Erasmus in the conflict with Luther. Seewald has shown that the main source for Hubmaier's Freedom of the Will II was Erasmus' Diatribe (Hubmaier 1962: 399). The three-fold division of the document and the biblical references which were utilized were gleaned from Erasmus. Thor Hall produced a comparative study of Hubmaier and Erasmus showing that their views regarding free will were analogous (Hall 1961: 149-70). Bergsten surmised 'that the impression made by Erasmus upon Hubmaier during his early years in Waldshut had a lasting effect'. He also added that there was no question 'that Hubmaier knew Erasmus' Diatribe' (Bergsten 1978: 35253). Although Hubmaier's arguments were not exactly the same as Erasmus', Pipkin and Yoder determined that, 'The clearest indication of the dependence of Hubmaier upon Erasmus is that Hubmaier tends to use the same Scriptures as Erasmus in the order in which Erasmus used them', regarding the subject of free will (Hubmaier 1989: 453). Pipkin and Yoder discussed Erasmus' and Hubmaier's utilization of identical Scripture passages in support of their free will positions (Hubmaier 1989: 426-91).

Erasmus taught that 'special grace (gratia peculiaris)' was what God utilized to rouse the sinner to repentance. By this special grace one could do good works and become eligible for the 'supreme grace (gratia gratum faci- 
ens)', which made the person acceptable to God. Salvation for Erasmus was initiated by God but required the free will response on the part of the person (semi-Augustinianism) (Payne 1970: 75-79). The Fall did not extinguish all 'understanding (realization of need for right relationship with God)', however such understanding was clouded. Consequently, the human will was not completely destroyed but became incapable of doing good works. Partly by God's command and partly by Scripture the inherent 'light', which dwells within each human being, awakens the 'understanding'. Erasmus wrote of the ratio which exists in fallen humanity and is illumined by the lux nativa. Hubmaier referred to it as a 'live spark' which cannot be destroyed by sin. Erasmus saw the imago Dei that remained after the Fall as mainly rational, but Hubmaier's understanding of the 'image of God' was more mystical and spiritualistic (Payne 1970: 75-79; Bergsten 1978: 352-54).

Erasmus and Hubmaier held to similar opinions on free will but their anthropological concepts of the doctrine were distinct. In siding with Erasmus' semi-Augustianism (or even semi-Pelgianism), Hubmaier had departed from mainstream Augustianism adhered to by most of the evangelical reformers. Luther and others in the majority held to the Augustinian tenets of predestination, irresistible grace, and perseverance of the saints. Luther focused on justification, whereas Hubmaier saw the new birth as primary. Luther keyed on the righteousness of Christ, which was accredited to humanity. Hubmaier was concerned with the change in a person as a result of the preached Word and the Holy Spirit (Payne 1970: 75-79; Bergsten 1978: 352-54). Erasmus leaned more toward 'immanent rationalism', whereas 'in Hubmaier's anthropology the supernatural element' was not questioned (Bergsten 1978: 352-53).

Freedom of the will was not the only topic Hubmaier broached in his catechism. The Anabaptist emphases upon anti-sacramentalism, anticlericalism, the authority of Scripture, salvation by grace through faith, pneumatology, discipleship, ecclesiology, believer's baptism, and suffering and martyrdom were evident in the catechism (Snyder 1995: 83-99). However, for Hubmaier, the theme of 'love', and especially the 'love of God and neighbor' (or in much of Hubmaier's usage, 'brother'), provided the foundation upon which Anabaptism would stand.

\section{Hubmaier and the Lehrtafel (1526/27)}

C. Arnold Snyder described Hubmaier's catechism as 'particularly valuable as a beginning reference point for identifying Anabaptist distinctives' because it was 'a very early, and also an unusually comprehensive, Anabaptist expression of theological and ecclesiological fundamentals' (Snyder 1995: 83-99). Balthasar Hubmaier penned his Lehrtafel (A Christian Catechism) in December of 1526 (Hubmaier 1989: 340). He composed the work at the 
request of Martin Göschl (Zeman 1969: 335). Göschl is important because: (1) he made the request for Hubmaier to compose a catechism; (2) he was a reform-minded humanist; and (3) he was a native southern Moravian who possessed knowledge of the indigenous religious parties and practices in Nikolsburg including the Utraquists and the Unitas Fratrum.

Hubmaier composed his catechism in order to provide a manual for instructing baptismal candidates. He desired to instruct adult believers and to teach the children of Anabaptist believers 'in order that the youth (to whom we owe a great responsibility) may be instructed in a proper and orderly way (recht und ordenlich vnderricht und anfengklich) and from childhood on [be] given food and drink and brought up with the teachings of Christ' (Hubmaier 1989: 341; Hubmaier 1962: 307). However, Zeman surmised that the intricate language used in some of the answers and the length of several responses showed that Hubmaier lost sight of his goal of educating youth (Zeman 1969: 335).

It is unclear how wide the circulation of the Lehrtafel actually was, but at least one source revealed that Hubmaier's catechetical work reached Great Britain! John Bale (former Carmelite turned Protestant around 1533, and later Bishop of Ossory) wrote a polemical tract published in Zürich in 1543 against Edmund Bonner, Bishop of London, and one of the most renowned leaders of the Catholic resurgence. Bale wrote about the seizure of a book in London by Balthasar Hubmaier called The Cathecisme of Pacimontanus. Bale wrote positively of Hubmaier's catechism and stated, 'Of Balthasar Hiebmeir Pacimontanus ys the thyrde catechysme, whom in dede I knowe not but by name, as I have redde yt in other mennys writinges. But I conceyue here the better opynyon of hym, for that my lorde hath condemned him amonge these menne, whose doctrine I knowe to be pure and perfyght' (Horst 1972: 94).

Hubmaier divided his catechism into two main parts. The 'First Part' discussed: (1) the knowledge of God; (2) salvation; (3) baptism; and (4) the church. The 'Second Part' covered: (5) the Lord's Supper; (6) worship; and (7) human nature and eternal redemption (Zeman 1969: 332-33).

The Lehrtafel consisted of ninety-nine questions and answers. It utilized a hypothetical dialogue between the Lords von Liechtenstein-Leonhard and his nephew Hans (Zeman 1969: 332-33; Hubmaier 1989: 339). In his introductory material to the Lehrtafel, Hubmaier reminded his friend Göschl of the essence of Anabaptism:

We have long known well that a Christian life must begin with the teaching from which faith flows (das ein Christenlich leben erstlich an der leer anfahen mů $\beta$, au $\beta$ wölher der Glaub herfleüset), and that accordingly water baptism follows afterward in accord with its institution by Christ (darn ach der Wassertauff in halt der einsetzunng Christi hernach volget), by which a person in a public confession of his 
faith (durch wölchen der mensch in der offenntlichen bekanndtnů $\beta$ seines glaubens) makes his first entry and initiation into the holy, universal Christian church (outside of which there is no salvation) for the forgiveness of his sins (Hubmaier 1989: 341; Hubmaier 1962: 307).

Hubmaier gave specific reasons for the necessity of his catechism. In the introduction to the Lehrtafel Hubmaier stated:

We therefore desire wholly and sincerely, in writing, in teaching, and in deed, to give to all those who through us fell into the same darkness and pit cause to open their eyes, to cry to God for enlightenment (zu Gott vmb erleüchtung schreyen), to arise from the fall, and to reform their lives (ir leben bessern). To this end may the power of God (die krafft Gottes) help them. Amen (Hubmaier 1989: 342; Hubmaier 1962: 308).

Hubmaier, a former Catholic leader and teacher, took responsibility for misleading others so that they fell 'into the same darkness and pit'. This was due to his ignorance, but he now desired to rectify the situation through the relaying of correct doctrine in his Lehrtafel (Hubmaier 1989: 342; Hubmaier 1962: 308).

Regarding the Catholic Church, Hubmaier conceded that the church did draw some truth from the gospel, but because 'so much chaff and grit of human comments and additions are mixed with them that we have not tasted the sweetness of the real wheat and kernel' and therefore there could be no real 'salvation' there (Hubmaier 1989: 341; Hubmaier 1962: 307).

Hubmaier emphasized the theme of 'love', especially the two-fold 'love of God and neighbor', throughout his catechism. To be exact, in the seven sections of the Lehrtafel, he stressed the premise of 'love' in five of them (Hubmaier 1989: 345, 351; Hubmaier 1962: 311, 315). In the section on 'salvation', Hubmaier identified 'love' as the defining characteristic of true or 'living faith' (Hubmaier 1989: 348; Hubmaier 1962: 313). Leonhart asked his nephew the question, 'What is dead faith?' Hans replied, 'One that is unfruitful and without the works of love, James 2: 17.' Leonhart then continued, 'What is living faith?' Hans responded, 'One that produces the fruits of the Spirit and works through love, Galatians 5' (Hubmaier 1989: 348; Hubmaier 1962: 313). Hubmaier pointed out that his soteriology was not based on works, but instead through love one exemplified 'living' or professing faith which would reveal fruits of the Spirit and good works.

In his discussion of the 'church', Hubmaier noted the importance of 'love' in the practice of church discipline or fraternal admonition. He had Leonhart ask, 'What authority do those in the church have over one another?' Hans replied, 'The power of fraternal admonition.' Leonhart then inquired, 'What is fraternal admonition?' Hans answered, 'One who sees his 
brother sin goes to him in love (zi im geet auß liebe) and admonishes him fraternally and quietly (strafft in brüderlich in der still) to abandon such sin. If he desists, he has won his soul' (Hubmaier 1989: 352-53; Hubmaier 1962: 316). Hubmaier emphasized 'fraternal admonition (briderlich straff)' or 'brotherly love' which instilled mutual accountability within the congregation. His Anabaptist ecclesiology was set apart from the priestly admonition in the Catholic Church, which lacked mutual accountability between clergy and laity.

The theme of 'love' continued to be prominent in Hubmaier's description of the Lord's Supper. For him, the Supper depicted a 'testimonial' love, one which portrayed the essence of brotherly love as a public testimony (Hubmaier 1989: 354; Hubmaier 1962: 317). Leonhart posed this question to his nephew: 'What is the Lord's Supper?' Hans responded:

It is a public sign and testimonial of the love in which one brother obligates himself to another before the congregation (Es ist ein offenlich zaychen vnnd zeügknu $\beta$ der liebe, in der sich ain bruder verpflicht mit dem anndern vor der Kirchen) that just as they now break and eat the bread with each other and share and drink the cup, likewise they wish now to sacrifice and shed their body and blood for one another; this they will do in the strength of our Lord Jesus Christ, whose suffering they are now commemorating in the Supper with the breaking of bread and the sharing of the wine, and proclaiming his death until he comes. Precisely this is the pledge of love in Christ's Supper (die Liebpflicht des Nachtmals Christi) that one Christian performs toward the other, in order that every brother may know what good deed to expect from the other (was güts er sich zu dem andern versehen sole) (Hubmaier 1989: 354; Hubmaier 1962: 317).

Hubmaier revealed a communal ecclesiology of the sacraments in that the meal was shared 'for one another'. Leonhart then continued with a question regarding transubstantiation, 'Is the bread not the body of Christ and the wine his crimson blood, as the Maoz-priests have been telling us?' Hans replied resoundingly:

By no means; the bread and wine are nothing but memorial symbols of Christ's suffering and death for the forgiveness of our sins. This on the basis of the institution by Christ on Maundy Thursday when he was about to go out and show us the greatest of all signs of love (das aller gröst Liebzaichen beweysen), on the next day giving his flesh and blood unto death on our account, which our forefathers consequently called Good Friday (Karfreitag) from caritate, i. e., from love. Indeed, to state it bluntly, the Lord's Supper is a sign of the obligation to brotherly love (ein pflichtzaichen briderlicher liebe) just as water baptism is a symbol of the vow of faith (der wassertauff ein glübdzaychen ist des glaubens). The water concerns God, the Supper our neighbor; therein lie all the Law and the Prophets. No other ceremonies were instituted by Christ and left behind on earth, and whoever correctly teaches these two signs teaches faith and love correctly (ond wölher die zway 
zaichenn recht leeret, der leeret recht den glauben wnd liebe) (Hubmaier 1989: 354-55; Hubmaier 1962: 317-18).

Hubmaier described the Lord's Supper as an 'obligation to brotherly love' and expressed baptism as a 'symbol of the vow of faith'. His theology of the sacraments showed a consistency in his earlier thought by focusing on "mutual admonition' (Hubmaier 1989: 354-55; Hubmaier 1962: 317-18).

Erasmus identified the 'sum of all law' as the 'love of God and neighbor' in his call for the renewal of catechization. Hubmaier echoed a similar emphasis in his catechism in the section on 'worship'. Leonhart inquired, 'In what does the sum of all preaching lie (War inn steet die sum aller Predigen)?' Hans replied, 'In love.' Leonhart then responded, 'In what way?' Hans plainly stated, 'That I love the Lord my God with my whole heart, my whole soul, and all my strength, and my neighbor as myself. If I do that, I have fulfilled all the Law and the Prophets' (Hubmaier 1989: 359; Hubmaier 1962: 320). Hubmaier's usage of the 'sum of all preaching' instead of 'law' reiterated his emphasis on the impact of the preached Word upon the lives of the hearer sent out of love.

Hubmaier's final discussion of 'love' in the Lehrtafel was in the section on 'human nature and eternal redemption' (Hubmaier 1989: 362; Hubmaier 1962: 333). In his analysis of rewards and good works, he described the relationship between a father and a son. It was through that intimate relationship Hubmaier concluded, 'A good son does not serve his father for pay, but out of love' (Hubmaier 1989: 362; Hubmaier 1962: 323).

Hubmaier taught on baptism in the Lehrtafel as well. The baptismal theology presented in Leonhard Schiemer's Anabaptist catechism, the second published Anabaptist catechism (Graffagnino 2008: 171-204, 224-252), mirrored that of Hubmaier (Graffagnino 2008: 190-94). In On the Christian Baptism of Believers (1525), Hubmaier described different kinds of baptism and what they meant. He detailed five types of baptism:

1. Baptism in water (Täuffen im wasser).

2. Baptism in water, for or unto a change of life (in oder zů endrung des lebens).

3. Baptism in the Spirit and fire (Täuffen im geyst ond feür).

4. To be reborn out of water and Spirit (Widergeboren warden au $\beta$ dem wasser und geyst).

5. Baptism in water in the name of the Father, Son, and Holy Spirit, or in the name of our Lord Jesus Christ (inn dem nammen des Vatters, Süns und des heyligen Geysts, oder inn dem nammen unsers Jhesu Christi) (Hubmaier 1989: 99; Hubmaier 1962: 121). 
Hubmaier noted that 'baptism in water' was in accordance 'to the divine command' and was the act of pouring 'outward water over the person who confesses his sins' and has agreed to count himself 'among the number of sinners'. The example of the first type of baptism was that of John the Baptist, according to Hubmaier. The 'baptism in water, for or unto a change of life' was the same as the first type of baptism, except that the purpose was to lead the person 'into a new life according to the Rule of Christ, Matthew 3: $11 \mathrm{ff}$ '. The 'baptism in the Spirit and fire' was 'to make alive and whole again the confessing sinner with the fire of the divine Word by the Spirit of God'. This type of baptism was the 'internal' change which took place 'in the human being'. Also according to Hubmaier, 'to be reborn out of water and Spirit' was 'to help the sinner out of the fear and dread which he [or she] received when his [or her] sins were pointed out' and by the letter of the law provided 'medicine and comfort again through the Word of God which will remain for eternity, so that' there will be no despair. The final type of baptism was 'baptism in water in the name of the Father, and the Son, and the Holy Spirit, or in the name of our Lord Jesus Christ', which was simply a 'public confession and testimony' of the person's 'faith in the name of Christ before everyone' (Hubmaier 1989: 99-100; Hubmaier 1962: 121-22).

In his Lehrtafel, Hubmaier had developed further his view of the kinds of baptism and narrowed them to three. He was the first to describe baptism in terms of 'water, Spirit, and blood'. The dialogue between the catechist and the catechumen went as follows:

Leonhart: How many kinds of baptism are there? Hans: Three kinds. Leonhart: What are they? Hans: A baptism of the Spirit (Ein Tauff des geysts), a baptism of water (Ein tauff des Wassers), and a baptism of blood (Ein tauff des blits). Leonhart: What is the baptism of the Spirit? Hans: It is an inner illumination of our hearts (ein jnwendige erleüchtung vnnserer hertzen) that takes place by the Holy Spirit, through the living Word of God. Leonhart: What is water baptism? Hans: It is an outward and public testimony of the inner baptism in the Spirit (ein eüsserlich vnd offentliche zeugnuß des inwendigen Tauffs im geyst), which a person gives by receiving water, with which one confesses one's sins before all people... publicly and orally vows to God (offenntlich vnd münndtlich Got) and agrees in the strength of God the Father, Son, and Holy Spirit that he [or she] will henceforth believe and live according to his divine Word... Leonhart: What is the baptism of blood? Hans: It is a daily mortification of the flesh until death (ein tegliche tödtung des fleyschs biß in den todt) (Hubmaier 1989: 349-50; Hubmaier 1962: 313-14).

\section{Summation of Balthasar Hubmaier's Theological Emphases}

Upon his arrival in Nikolsburg in the summer of 1526 Hubmaier found a multidimensional religious landscape open to reform ideas and ripe for the rise of Anabaptism. The indigenous Unitas Fratrum was an important toler- 
ated religious minority. Many of the elites among the nobles and clergy had been influenced by Erasmian Christian humanism. There were also reformminded Catholics and Utraquists that had joined together in calling for church reform.

Hubmaier established friendships quickly with many of the evangelical leaders. In terms of social prestige, Göschl was the most prominent leader of Moravian theological reform. He was an indigenous Moravian, a learned humanist, and a key figure in calling together reform-minded Catholic and Utraquist priests to discuss possible theological and ecclesiological changes in Moravia.

Spittelmaier probably introduced the Liechtenstein Lords to evangelical reforming thought when he arrived in Nikolsburg in 1524. He claimed to be the chaplain of the Liechtensteins and preached against the hypocrisy and arrogance of monks and their practices. His understanding of the Christian faith reflected some of the tenets of early Lutheran reforming thought.

Glaidt arrived in Nikolsburg one year prior to Hubmaier. He leaned toward the teachings of Zwingli. He recorded the debate called for by Göschl in his Handlung. The debate resulted in seven articles of reform, which included: preaching from the Scriptures only, viewing the Lord's Supper as a 'remembrance' of Christ, allowing ministers to marry, and removing anything from ecclesiastical worship which could lead to superstition (i. e. holy water, candles, etc.). Although Glaidt held to a symbolic understanding of the Lord's Supper and baptism (as Zwingli), he defended infant baptism prior to Hubmaier's arrival. Within six months of his arrival in Nikolsburg Hubmaier had won Göschl, Spittelmaier, Glaidt, as well as the Liechtensteins to Anabaptist faith.

Hubmaier became enamored with humanism and began reading Erasmus in 1521. He developed friendships with several well-known humanists during that time including Sapidus, Rhenanus, Rychard, and Adelphi. Hubmaier met with Erasmus in June 1522. In his Old and New Teachers in Believer's Baptism (1526) Hubmaier quoted Erasmus' Paraphrases and his apparent call for pre-baptismal instruction. However, the most distinct example of like-mindedness between Erasmus and Hubmaier was on the subject of free will.

Hubmaier initially addressed the issue of free will in his Lehrtafel $(1526 / 27)$. The crux of his doctrine of free will is that the soul may become 'healthy' as it was before the Fall and able to do good. When one is born again (wiederbeboren) through the Holy Spirit and the Word of God, the person is restored or brought back (wiederbringen) to his or her condition prior to the Fall, the image of God (die Bildung Gottes). Hubmaier described the image of God (imago Dei) as the 'inbreathing of God' and as a 'live spark'. 
The 'preached Word of God' (dem gepredigten wort Gottes) was the bearer of conviction upon the person. Through the power of the Holy Spirit the 'live spark' became awakened.

Hubmaier's writings on free will show him to be a sympathizer of Erasmus in the conflict with Luther. Hubmaier agreed with Erasmus' semiAugustinian view, which put Hubmaier in the minority among those debating free will at Nikolsburg. Erasmus taught that 'special grace (gratia peculiaris)' was what God utilized to rouse the sinner to repentance. The Fall did not extinguish all 'understanding (realization of need for right relationship with God)'. Erasmus wrote of the ratio which exists in fallen humanity and is illuminated by the lux nativa. Hubmaier referred to it as a 'live spark'. Hubmaier and Erasmus held similar opinions on free will, with Erasmus' leaning more towards 'immanent rationalism', whereas Hubmaier never questioned the supernatural element. Hubmaier developed his thought on the imago Dei in his Lehrtafel.

Göschl requested that Hubmaier compose a catechism in order to provide a manual for instructing baptismal candidates. Göschl was both a learned humanist and a native Moravian, familiar with the indigenous Unitas Fratrum and its catechetical practices.

When Hubmaier arrived in Nikolsburg he had not yet written a catechism to be used in pre-baptismal instruction. Hubmaier understood that for true baptism to take place the person must be 'brought through the Word of God to the recognition of his sin' and be 'taught by the Word of God that he should call upon God the Father for the forgiveness of his sin'. If the person calls upon the Father 'in faith... then God has cleansed his heart' and the person gives 'a public testimony of his internal faith and lets himself be baptized with water' (Hubmaier 1989: 117; Hubmaier 1962: 136). Hubmaier's baptismal practice prior to his arrival in Nikolsburg was: (1) hearing the Word of God preached, which leads one to repentance; (2) public profession of faith; and (3) baptism with water.

At Göschl's request Hubmaier composed the first Anabaptist catechism. He responded to his good friend's request in the introduction to Lehrtafel:

We have long known well that a Christian life must begin with the teaching from which faith flows, and that accordingly water baptism follows afterward in accord with its institution by Christ, by which a person in a public confession of his faith makes his first entry and initiation into the holy, universal Christian church (outside of which there is no salvation) for the forgiveness of his sins... Your Grace [Göschl] knows and recognizes that it is not enough to know that one must be taught and instructed before receiving baptism... but that it is also necessary to say what it is that one should first learn and know (Hubmaier 1989: 341; Hubmaier 1962: 307). 
After the composition of his catechism Hubmaier modified his baptismal practice to include: (1) hearing the Word of God preached, which leads one to repentance; (2) instruction through catechization; (3) a profession of one's faith followed by a baptismal vow; and (4) triune baptism by pouring or sprinkling (Rothkegel 2007: 170-71). Prior to his arrival in Nikolsburg, Hubmaier's baptismal practice did not include any mention of instruction through catechization before baptism.

The theme of 'love (die Liebe)' or more specifically the 'love of God and neighbor' or 'brotherly love' was a key foundational principle in Lehrtafel. Hubmaier emphasized 'fraternal admonition (briderlich straff)' or 'brotherly love' which instilled mutual accountability within the congregation. He revealed his communal ecclesiology toward the sacraments. Whereas Erasmus had identified the sum of all law as the 'love of God and neighbor', Hubmaier described the 'sum of all preaching' as love thereby reiterating the importance of the preached Word upon the hearer in order to differentiate Anabaptist thought and practice from the crowded theological landscape.

\section{Bibliography}

Bergsten T (1978) Balthasar Hubmaier. Anabaptist Theologian and Martyr. Barnes IJ and Estep WR (eds), Estep WR (trans). Valley Forge, PA: Judson Press.

Davis KR (1974) Anabaptism and Asceticism. A Study of Intellectual Origins. Scottdale, PA: Herald Press.

Erasmus D (1974-2004) The Collected Works of Erasmus. Volumes 1-84, Sider RD (trans and ed). Toronto: University of Toronto Press.

Graffagnino JJ (2008) The Shaping of the Two Earliest Anabaptist Catechisms. PhD Thesis, Southwestern Baptist Theological Seminary, USA.

Halkin LE (1993) Erasmus. A Critical Biography. Tonkin J (trans). Oxford: Blackwell Publishers.

Hall T (1961) Possibilities of Erasmian Influence on Denck and Hubmaier in their Views on the Freedom of the Will. Mennonite Quarterly Review 35(*): 149-70.

Horst IB (1972) The Radical Brethren. Anabaptism and the English Reformation to 1558. Nieuwkoop: B De Graaf.

Hubmaier B (1962) Balthasar Hubmaier. Schriften. Westin G and Bergsten T (eds). Gütersloher: Gerd Mohn.

Hubmaier B (1989) Balthasar Hubmaier. Theologian of Anabaptism. Pipkin HW and Yoder JH (eds). Scottdale, PA: Herald Press.

Payne JB (1970) Erasmus. His Theology of the Sacraments. Peoria, IL: Bratcher ME. 
Rothkegel M (2007) Anabaptism in Moravia and Silesia. In Roth JD and Stayer JM (eds) A Companion to Anabaptism and Spiritualism, 1521-1700. Brill's Companions to the Christian Tradition. Volume 6. Leiden: Brill, pp. 163-215.

Shantz DH (1992) Crautwald and Erasmus. A Study in Humanism and Radical Reform in Sixteenth Century Silesia Baden-Baden: Valentin Koerner.

Snyder CA (1995) Anabaptist History and Theology. An Introduction. Kitchener, ON: Pandora Press.

Steinmetz DC (2001) Reformers in the Wings. From Geiler von Kaysersberg to Theodore Beza. Oxford: Oxford University Press.

Vedder HC (1905) Balthasar Hübmaier. The Leader of the Anabaptists. New York: Knickerbocker Press.

Zeman JK (1967) Historical Topography of Moravian Anabaptism. Mennonite Quarterly Review 41(*): 116-60.

Zeman JK (1969) The Anabaptists and the Czech Brethren in Moravia 1526-1628. A Study of Origins and Contacts. The Hague: Mouton Press. 